\title{
EKSTRAKSI Zr DAN Hf MENGGUNAKAN CAMPURAN EKTRAKTAN TBP DAN CYANEX 921
}

\section{EXTRACTION OF Zr AND Hf BY SOLVENT MIXTURE OF TBP AND CYANEX- 921}

\author{
Susanna Tuning S., Tri Handini, Dwi Biyantoro, Samin \\ Pusat Sains dan Teknologi Akselerator, BATAN \\ Jl. Babarsari Kotak Pos 6101 Ykbb, Yogyakarta 55281 \\ e-mail:susanna_ts@yahoo.com.
}

Diterima 1 September 2015, diterima dalam bentuk perbaikan 13 Oktober 2015, disetujui 14 Desember 2015

\begin{abstract}
ABSTRAK
EKSTRAKSI Zr DAN Hf MENGGUNAKAN CAMPURAN EKTRAKTAN TBP DAN CYANEX 921. Telah dilakukan ekstraksi larutan Zr yang mengandung Hf menggunakan campuran extraktan TBP dan Cyanex 921. Sebagai fasa air digunakan larutan campuran $\mathrm{ZrO}\left(\mathrm{NO}_{3}\right)_{2}$ dan $\mathrm{HfO}\left(\mathrm{NO}_{3}\right)_{2}$ yang mengandung $\mathrm{Zr} 26 \mathrm{gr} / \mathrm{L}$ dan $\mathrm{Hf}$ 0,5 gr/L dan penggaram $\mathrm{NaNO}_{3} 3,5 \mathrm{M}$, sedangkan ekstraktan atau fasa organik adalah campuran 30\% TBP dan Cyanex 921 dengan variasi konsentrasi yang diencerkan dengan kerosen. Parameter yang diteliti yaitu konsentrasi ekstraktan, kecepatan pengadukan, waktu pengadukan, dan perbandingan fasa air dan fasa organik. Untuk analisis Zr dan Hf digunakan metode X-Ray Fluorescence (XRF). Dari hasil optimasi proses ekstraksi Zr dan Hf dari larutan Zr-Hf dengan menggunakan campuran ekstraktan TBP dan Cyanex 921 diperoleh kesimpulan sebagai berikut: konsentrasi ekstraktan Cyanex 921 adalah 12,5\%, waktu pengadukan selama 25 menit dengan kecepatan pengadukan $500 \mathrm{rpm}$, dan perbandingan fasa air dan fasa organik 1 : 1,5. Pada kondisi ini diperoleh faktor pisah (FP) Zr-Hf=6,447, efisiensi ekstraksi Zr = 93,57\% dan untuk $H f=69,31 \%$ serta $K d Z r=14,556$ dan $K d H f=2,258$.
\end{abstract}

Kata kunci: ekstraksi, TBP, Cyanex 921, zirkonium, hafnium, kerosen, XRF.

\begin{abstract}
EXTRACTION OF Zr AND Hf BY SOLVENT MIXTURE OF TBP AND CYANEX- 921. The extraction of Zr and $\mathrm{Hf}$ using solvent mixture of TBP and Cyanex-921 has been done. As the water phase used a mixed solution of $\mathrm{ZrO}\left(\mathrm{NO}_{3}\right)_{2}$ and $\mathrm{HFO}\left(\mathrm{NO}_{3}\right)_{2}$ containing $\mathrm{Zr} 26 \mathrm{~g} / \mathrm{L}$ and $\mathrm{Hf} 0.5 \mathrm{~g} / \mathrm{L}$ and $3.5 \mathrm{M} \mathrm{NaNO}_{3}$, while the extractant or the organic phase used a mixture of 30\% TBP and Cyanex-921 with a variation of the concentration is diluted with kerosene. The parameters studied were extractant concentration, stirring speed, stirring time, and the ratio of aqueous phase and an organic phase. For the analysis of $\mathrm{Zr}$ and $\mathrm{Hf}$ is used the $\mathrm{X}$-Ray Fluorescence (XRF). From the results of the extraction process optimization $\mathrm{Zr}$ and $\mathrm{Hf}$ from $\mathrm{Zr}-\mathrm{Hf}$ solution using a mixture of TBP and Cyanex 921 extractant obtained the following conclusions: the concentration of Cyanex 921 extractant was $12.5 \%$, while stirring time for 25 minutes with a stirring speed of $500 \mathrm{rpm}$, and the ratio of the water phase and the organic phase was $1: 1.5$. In this condition acquired a separating factor $(F P) \mathrm{Zr}-\mathrm{Hf}=6.447$, the extraction efficiency of $\mathrm{Zr}=93.57 \%$ and $\mathrm{Hf}=69.31 \%$, while $\mathrm{KdZr}=$ 14.556 and $\mathrm{KdHf}=2.258$, respectively.
\end{abstract}

Keywords: extraction, TBP, Cyanex 921, zirconium, hafnium, kerosene, XRF.

\section{PENDAHULUAN}

Demurnian zirkonium (Zr) dari pengotor-pengotornya sangat diperlukan karena sebagai bahan struktur reaktor diperlukan $\mathrm{Zr}$ dengan kemurnian yang sangat tinggi (derajat nuklir). Salah satu pengotor yang harus dihilangkan adalah hafnium (Hf) yang mempunyai tampang serapan neutron tinggi (102 barn) yang dapat menyerap neutron yang seharusnya dipakai untuk mengadakan reaksi inti berantai (I). Sebagai bahan struktur reaktor, logam Zr mempunyai beberapa sifat unggul, yaitu tahan korosi terhadap air maupun uap air, tilik leleh tinggi, strukturnya kuat serta tampang serapan neutronnya rendah $(0,2$ barn $)(2,3)$. 
Zirkonium dan hafnium adalah unsur - unsur yang terletak di golongan IV dari tabel periodik. Unsur unsur ini mempunyai sifat-sifat kimia yang mirip sehingga kemampuan untuk membentuk senyawa atau ion komplek juga hampir sama. Hal ini yang menyebabkan kesulitan di dalam pemisahannya. Meskipun demikian ada sedikit perbedaan yaitu mengenai "ionic volume" yang berperan di dalam kestabilan dari bentuk kompleknya. Zirkonium mempunyai volume atom yang lebih besar ( $\mathrm{Zr}=13,97$ Angstrom kubik, $\mathrm{Hf}=13,42$ Angstrom kubik) tetapi $\mathrm{Hf}$ mempunyai volume ion yang lebih besar (jari-jari $\mathrm{Zr}^{+4}=0,74$ Angstrom dan jari-jari $\mathrm{Hf}^{+4}=0,75$ Angstrom). Kecenderungan $\mathrm{Zr}$ untuk bergabung dengan ion-ion lain lebih besar dari $\mathrm{Hf}$ sehingga senyawa komplek Zr lebih stabil dari senyawa komplek Hf (1).

Untuk pemisahan $\mathrm{Zr}$ dari Hf dipakai berbagai cara yang masing-masing cara menggunakan alat, pelarut dan sistem yang berlainan. Beberapa metode yang digunakan untuk pemisahan $\mathrm{Zr}$ dan $\mathrm{Hf}$, antara lain adalah kristalisasi fraksional (4), ekstraksi pelarut (5-9), pertukaran ion (10-13), distilasi ekstraktif dalam garam cair (14), kromatografi (15) dan sublimasi (16-18). Ekstraksi cair-cair dengan memakai pelarut dapat digunakan metil iso butil keton (MIBK) maupun tri butyl fosfat (TBP). Ekstraksi dengan TBP murni sering dilakukan, kecuali itu juga dipakai pengencer misalnya kerosin, $n$-heptan, $x$-ylene dan di butil ether.

Pemisahan zirkonium dan hafnium pada proses ekstraksi cair-cair dapat dilakukan dengan mengubah logam-logam tersebut menjadi senyawa kompleks yang dapat larut dalam fasa organik. Fasa organik ini mempunyai gugus ligan yang dapat bereaksi selektif terhadap salah satu atau beberapa unsur logam yang ada dalam fasa air. Terpisahnya unsur-unsur logam ini karena perbedaan reaktifitas dan difusifitas masing-masing unsur logam terhadap fasa organik.

Menurut hukum distribusi Nernst, bila dalam dua pelarut yang tidak saling bercampur dimasukkan solut yang dapat larut dalam kedua pelarut tersebut, maka akan terjadi pembagian kelarutan. Kedua pelarut tersebut umumnya pelarut organik dan air. Dalam campuran, solut akan terdistribusi dengan sendirinya ke dalam dua pelarut tersebut, setelah diaduk, kemudian dibiarkan maka akan terjadi 2 fasa yang terpisah. Perbandingan kosentrasi solut di dalam kedua pelarut tersebut tetap dan merupakan suatu tetapan pada suhu tetap. Tetapan tersebut dikenal dengan tetapan distrbusi atau koefisien distribusi.

Koefisien distribusi $\left(K_{d}\right)$ dinyatakan dengan rumus sebagai berikut (19):

$$
K_{d}=C_{2} / C_{1} \text { atau } K_{d}=C_{0} / C_{a}
$$

dengan:

$C_{1}$ atau $C_{a}$ adalah kosentrasi solut dalam pelarut pertama atau pelarut air.

$C_{2}$ atau $C_{0}$ adalah kosentrasi solut dalam pelarut kedua atau pelarut organik.

Sesuai dengan kesepakatan, kosentrasi solut dalam pelarut organik dituliskan di atas. Dari rumus di atas apabila harga $K_{d}$ besar, solut secara kuantitatif akan cenderung terdistribusi lebih banyak dalam pelarut organik dan demikian juga sebaliknya. Hukum distribusi Nernst ini banyak dipakai dalam proses ekstraksi, analisis dan penentuan tetapan kesetimbangan.

Pada penelitian ini akan dilakukan ekstraksi Zr-Hf dengan campuran ekstraktan TBP dan Cyanex 921, dimana penelitian ini masih baru dan belum pernah dilakukan orang. Penelitian yang mirip adalah pemisahan $\mathrm{Zr}$ Hf dengan campuran ekstraktan TBP dan Cyanex 923 oleh M. Taghizadeh dkk. (2011) (3). Hasil penelitian menunjukkan bahwa dalam suasana $\mathrm{HNO}_{3} 3,5 \mathrm{M}$, larutan umpan $26,5 \mathrm{~g} / \mathrm{Zr}$, menggunakan campuran TBP : Cyanex 923 adalah 60\% : 40\%, diperoleh efisiensi ekstraksi adalah 53\% untuk $\mathrm{Zr}$ dan $<1 \%$ untuk $\mathrm{Hf}$ dengan faktor pisah yang sangat tinggi yaitu 186. Apabila menggunakan TBP saja dalam suasana $\mathrm{HNO}_{3} 7 \mathrm{M}$, larutan umpan $20 \mathrm{~g} / \mathrm{l} \mathrm{Zr}$, menggunakan campuran TBP : Cyanex 923 adalah 60\%: 40\%, diperoleh efisiensi ekstraksi adalah $67 \%$ untuk $\mathrm{Zr}$ dan $14 \%$ untuk $\mathrm{Hf}$ dengan faktor pisah $=12$. Berdasarkan hasil penelitian ini, maka akan dicoba penelitian yang mirip yaitu ekstraksi Zr-Hf dengan campuran ekstraktan TBP dan Cyanex 921.

Penelitian ini bertujuan untuk mempelajari ekstraksi Zr-Hf dengan menggunakan campuran ekstraktan TBP dan Cyanex 921, mempelajari pengaruh parameter proses ekstraksi, dan mengetahui efisiensi ekstraksi $\mathrm{Zr}$ dan $\mathrm{Hf}$, faktor pemisahan $\mathrm{Zr}-\mathrm{Hf}$ serta harga $\mathrm{Kd}$ untuk $\mathrm{Zr}$ dan $\mathrm{Hf}$ pada variasi kondisi proses ekstraksi.

Cyanex 921 adalah tri-n-oktilfosfina oksida yang memiliki sifat fisis seperti kristal lilin, meleleh pada suhu $51{ }^{\circ} \mathrm{C}$, dengan titik didih pada tekanan $1 \mathrm{~atm}$ sebesar $200{ }^{\circ} \mathrm{C}$, dapat larut pada hampir semua senyawa hidrokarbon. Kelarutan tertinggi terjadi dalam sikloheksana pada suhu $25{ }^{\circ} \mathrm{C}$ yaitu $0,9222 \mathrm{~mol} / \mathrm{L}$. Cyanex 921 
tidak larut dalam air. Kelarutan Cyanex 921 bertambah sebanding dengan naiknya suhu (1). Reaksi kimia yang terjadi antara zirkonium/hafnium dengan Cyanex 921 adalah sebagai berikut (1):

$$
\mathrm{M}\left(\mathrm{NO}_{3}\right)_{4}+4 \mathrm{R}_{3} \mathrm{PO} \rightarrow \mathrm{M}\left(\mathrm{NO}_{3}\right)_{4} \cdot 4 \mathrm{R}_{3} \mathrm{PO}
$$

Pengencer kerosen dipilih karena dapat meningkatkan efisiensi pemisahan $\mathrm{Zr}$ dan memperbesar kemampuan ekstraktan dalam membentuk komplek dengan Zr.

Reaksi ekstraksi pemisahan $\mathrm{Zr}-\mathrm{Hf}$ ditulis sbb (9):

$$
\begin{aligned}
& \mathrm{ZrO}_{2}++4 \mathrm{NO}_{3}^{-}+2 \mathrm{H}++2 \mathrm{TBP} \leftrightarrow \mathrm{Zr}\left(\mathrm{NO}_{3}\right)_{4} 2 \mathrm{TBP}+\mathrm{H}_{2} \mathrm{O} \\
& \mathrm{HfO}_{2}++4 \mathrm{NO}_{3}{ }^{-}+2 \mathrm{H}++2 \mathrm{TBP} \leftrightarrow \mathrm{Hf}\left(\mathrm{NO}_{3}\right)_{4} 2 \mathrm{TBP}+\mathrm{H}_{2} \mathrm{O}
\end{aligned}
$$

\section{METODOLOGI}

\section{Bahan}

Bahan-bahan yang digunakan dalam penelitian ini adalah $\mathrm{ZrOCl}_{2} .8 \mathrm{H}_{2} \mathrm{O}, \mathrm{HfOCl}_{2} .8 \mathrm{H}_{2} \mathrm{O}, \mathrm{HNO}_{3} 3 \mathrm{~N}$ dan penggaram $\mathrm{NaNO}_{3} 3,5 \mathrm{M}$. Ekstraktan yang digunakan dalam penelitian adalah TBP dan Cyanex 921 yang diencerkan dengan kerosen.

\section{Alat}

Alat yang digunakan adalah seperangkat alat spektrometer pendar sinar-X (Ortec 7010), pengaduk dan pemanas magnetik ( $\mathrm{ka}{ }^{\circledR}$ Werke), neraca analitik (Sartorius 2464), alat-alat gelas kimia, vial, dan spex film.

\section{Cara kerja}

1. Dibuat larutan umpan sebanyak $500 \mathrm{ml}$ dengan cara menimbang $45,925 \mathrm{~g} \mathrm{ZrOCl}_{2} .8 \mathrm{H}_{2} \mathrm{O}$ dan $0,574 \mathrm{~g}$ $\mathrm{HfOCl}_{2} .8 \mathrm{H}_{2} \mathrm{O}$, dilarutkan dengan $\mathrm{HNO}_{3} 3 \mathrm{~N}$ sehingga diperoleh larutan umpan dengan kadar $\mathrm{Zr} 26 \mathrm{gr} / \mathrm{L}$ dan Hf $0,5 \mathrm{gr} / \mathrm{L}$. Sebagai penggaram dipakai larutan $\mathrm{NaNO}_{3} 3,5 \mathrm{M}$.

2. Proses ekstraksi dilakukan dengan cara mengambil $10 \mathrm{~mL}$ larutan umpan $\mathrm{Zr}-\mathrm{Hf}$, ditambah dengan campuran ekstraktan TBP : Cyanex $921=30 \%: 5 \%$ dan kerosen $65 \%$, perbandingan fasa air dengan fasa organik FA : $\mathrm{FO}=1: 1$, kecepatan pengadukan $400 \mathrm{rpm}$ dan waktu pengadukan 5 menit. Fasa air dipisahkan dari fasa organik untuk dianalisis kadar $\mathrm{Zr}$ dan $\mathrm{Hf}$ dengan alat XRF. Ekstraksi dilanjutkan dengan beberapa parameter, yaitu variasi konsentrasi Cyanex 921 dalam fasa organik, variasi kecepatan pengadukan, waktu pengadukan/ekstraksi, dan perbandingan FA : FO. Di sini konsentrasi TBP dibuat tetap 30\%, sedangkan konsentrasi Cyanex 921 dan kerosene tidak tetap.

3. Untuk mempelajari variasi konsentrasi (\%) Cyanex 921, dibuat larutan campuran ekstraktan $30 \%$ TBP dan Cyanex 921 dengan variasi konsentrasi $0,2,5,5,7,5,10,12,5,15$ dan 17,5\%, dengan pengencer kerosen, masing-masing sebanyak $10 \mathrm{~mL}$. Masing-masing ditambah dengan $10 \mathrm{~mL}$ larutan umpan, dicampur dan diaduk selama 5 menit pada kecepatan pengadukan $400 \mathrm{rpm}$ dengan perbandingan FA : FO = $1: 1$. Campuran kemudian dipisahkan dengan corong pisah. Fasa air dianalisis. Konsentrasi ekstraktan yang memberikan nilai faktor pisah tertinggi digunakan untuk proses ekstraksi selanjutnya.

4. Pada variasi kecepatan pengadukan, diambil larutan umpan $10 \mathrm{~mL}$ masing-masing dimasukkan ke dalam 10 $\mathrm{mL}$ larutan campuran ekstraktan 30\% TBP dan konsentrasi Cyanex 921 hasil optimasi sebelumnya, kemudian diaduk dan dipisahkan.campuran umpan dan ekstraktan dilakukan dengan variasi kecepatan pengadukan dari: 200, 300, 400, 500, 600, 700 dan 800 rpm. Dari hasil analisis yang dapat memberikan faktor pisah $\mathrm{Zr}$ dan $\mathrm{Hf}$ tertinggi digunakan untuk proses ekstraksi berikutnya.

5. Untuk variasi waktu ekstraksi dilakukan dengan cara pengadukan umpan dan ekstraktan selama $5,10,15$, 20, 25, 30 dan 35 menit. Diambil larutan umpan $10 \mathrm{~mL}$ masing-masing dimasukkan ke dalam larutan campuran ekstraktan 30\% TBP dan konsentrasi Cyanex 921 hasil optimasi sebelumnya, dan pada kecepatan pengadukan yang optimum, kemudian diaduk dan dipisahkan. Dari hasil analisis yang dapat memberikan nilai faktor pemisahan $\mathrm{Zr}$ dan $\mathrm{Hf}$ tertinggi digunakan untuk proses selanjutnya.

6. Pada variasi perbandingan $\mathrm{FO}: \mathrm{FA}$ dilakukan dengan cara pengadukan umpan dan ekstraktan mulai dari FO $: F A=1: 0,5,1: 1,1: 1,5,1: 2,0$ dan $1: 2,5$. Diambil larutan umpan masing-masing sebanyak $10 \mathrm{~mL}$, dimasukkan ke dalam larutan campuran ekstraktan 30\% TBP dan konsentrasi Cyanex 921 hasil optimasi 
sebelumnya, dan pada kecepatan dan waktu pengadukan yang optimum, kemudian diaduk dan dipisahkan. Dari hasil analisis yang dapat memberikan faktor pisah $\mathrm{Zr}$ dan $\mathrm{Hf}$ tertinggi digunakan untuk proses ekstraksi berikutnya.

\section{HASIL DAN PEMBAHASAN}

\section{Variasi Konsentrasi Cyanex 921}

Konsentrasi ekstraktan Cyanex 921 sangat berpengaruh dalam proses ekstraksi pemisahan $\mathrm{Zr}-\mathrm{Hf}$. Harga koefisien distribusi $\left(K_{d}\right)$, efisiensi ekstraksi $(\% E)$ dan faktor pisah $(F P)$ yang diperoleh dari variasi konsentrasi Cyanex 921 disajikan dalam Tabel 1 dan Gambar 1. Pada Tabel 1 dan Gambar 1 ditunjukkan bahwa semakin besar konsentrasi Cyanex 921 maka nilai $K_{d}$ cenderung naik, hal ini disebabkan karena semakin tinggi konsentrasi ekstraktan maka semakin banyak terbentuk senyawa komplek dengan logam. Dengan demikian faktor pisah $\mathrm{Zr}$-Hf juga semakin besar dengan meningkatnya konsentrasi ekstraktan yang digunakan. Sama seperti penelitian yang telah dilakukan oleh $\mathrm{M}$. Taghizadeh dkk. (3) yang menggunakan campuran ekstraktan TBP dan Cyanex 923, diperoleh hasil bahwa faktor pemisahan $\mathrm{Zr}-\mathrm{Hf}$ meningkat dengan meningkatnya konsentrasi ekstraktan (Cyanex 923).

Tabel 1. Variasi konsentrasi (\%) Cyanex-921 (Perbandingan FA : FO $=1: 1$, waktu pengadukan $=5$ menit, kecepatan pengadukan $=400 \mathrm{rpm})$.

\begin{tabular}{lcccc}
\hline No. & $\begin{array}{c}\text { Konsentrasi } \\
\text { Cyanex-921, } \%\end{array}$ & \multicolumn{2}{c}{ Koefisien distribusi $\left(K_{\mathrm{d}}\right)$} & Faktor pisah $(F P)$ \\
\cline { 3 - 5 } & 0,0 & $\mathrm{Hf}$ & $\mathrm{Zr}$ & $\mathrm{Zr} / \mathrm{Hf}$ \\
\hline 1. & 2,5 & 0,050 & 0,143 & 2,860 \\
\hline 3. & 5,0 & 0,211 & 0,636 & 2,872 \\
\hline 4. & 7,5 & 0,474 & 1,408 & 2,970 \\
\hline 5. & 10,0 & 0,577 & 1,918 & 3,324 \\
\hline 6. & 12,5 & 0,612 & 2,150 & 3,512 \\
\hline 7. & 15,0 & 0,648 & 2,432 & 3,753 \\
\hline 8. & 17,5 & 0,611 & 2,364 & 3,618 \\
\hline
\end{tabular}

Pada variasi konsentrasi Cyanex 921, diperoleh bahwa hasil faktor pisah ( $F P) \mathrm{Zr} / \mathrm{Hf}$ yang paling tinggi $(3,753)$ yaitu pada penambahan $12,5 \%$ Cyanex 921.

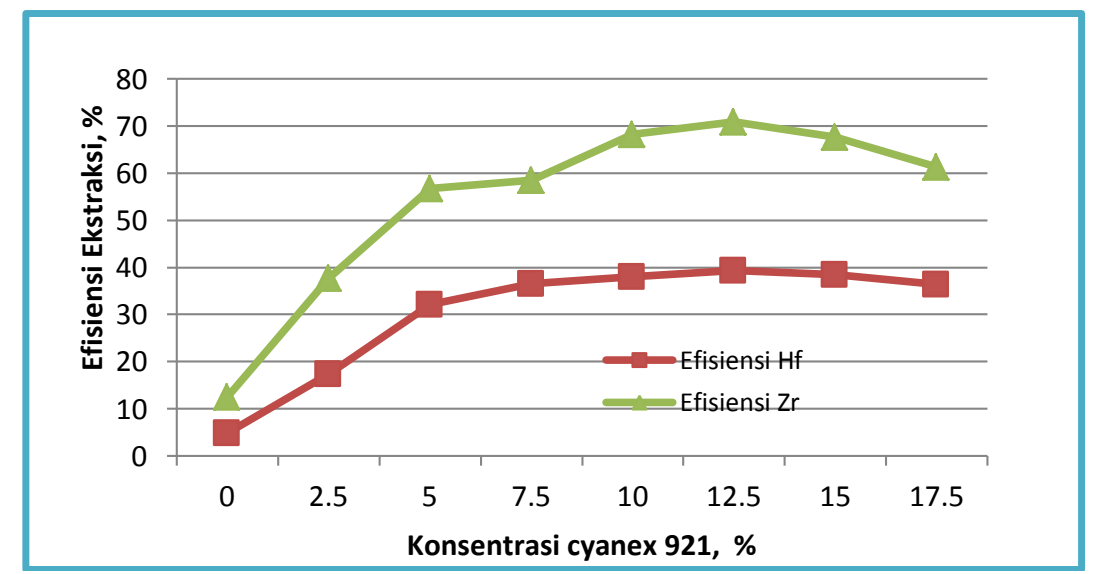

Gambar 1. Pengaruh konsentrasi Cyanex 921 terhadap efisiensi ekstraksi Zr/Hf. 
Dari Tabel 1, variasi konsentrasi Cyanex 921, diperoleh hasil bahwa faktor pisah $(F P) \mathrm{Zr} / \mathrm{Hf}$ yang paling tinggi $(3,753)$ yaitu pada penambahan $12,5 \%$ Cyanex 921 . Pada kondisi ini diperoleh harga koefisien distribusi $\left(K_{d}\right) \mathrm{Zr}=2,432$ dan $\mathrm{Hf}=0,648$. Pada proses ekstraksi $\mathrm{Zr}-\mathrm{Hf}$ memakai campuran ekstraktan Cyanex 921 dan TBP, dipilih yang dapat memberikan faktor pisah terbesar yaitu ekstraksi umpan suasana nitrat. Semakin tinggi konsentrasi ekstraktan maka akan semakin baik mengekstraksi unsur-unsur dalam umpan, hal ini ditandai dengan naiknya harga $K_{\mathrm{d}}$. Tetapi setelah mencapai konsentrasi tertentu nilai $K_{\mathrm{d}}$ akan semakin menurun karena pada konsentrasi ekstraktan yang semakin besar perpindahan solut dari fasa air ke fasa organik akan semakin sulit (20).

\section{Variasi Kecepatan Pengadukan}

Faktor kecepatan pengadukan dalam proses ekstraksi akan menyebabkan distribusi solut dari fasa air ke fasa organik semakin besar pula, tetapi kecepatan pengadukan yang terlalu cepat akan menyebabkan kontak antara fasa air dan fasa organik tidak optimum.

Hasil koefisien distribusi $\left(K_{d}\right)$, faktor pisah $(F P)$, dan efisiensi ekstraksi $(\% E)$ disajikan pada Tabel 2 dan Gambar 2. Pada Tabel 2 dan Gambar 2 menunjukkan adanya kenaikkan nilai $K_{d}$ dan efisiensi ekstraksi $Z r$ dan $\mathrm{Hf}$ seiring dengan kenaikan kecepatan pengadukan. Kondisi optimum yang dipilih berdasarkan nilai faktor pisah $(F P)$ antara $\mathrm{Zr}$ dan $\mathrm{Hf}$ yang terbesar.

Tabel 2. Variasi kecepatan pengadukan (Perbandingan FA : FO $=1: 1$, waktu pengadukan $=5$ menit, konsentrasi Cyanex $921=12,5 \%$ )

\begin{tabular}{lcccc}
\hline \multirow{2}{*}{ No. } & \multirow{2}{*}{$\begin{array}{c}\text { Kecepatan } \\
\text { pengadukan, rpm }\end{array}$} & \multicolumn{2}{c}{ Koefisien distribusi $\left(K_{\mathrm{d}}\right)$} & Faktor pisah $(F P)$ \\
\cline { 3 - 5 } & 200 & $\mathrm{Hf}$ & $\mathrm{Zr}$ & $\mathrm{Zr} / \mathrm{Hf}$ \\
\hline 1. & 300 & 0,561 & 0,938 & 0,672 \\
\hline 2. & 400 & 0,648 & 1,132 & 1,856 \\
\hline 3. & 500 & 0,670 & 2,432 & 3,753 \\
\hline 4. & 600 & 0,761 & 2,694 & 4,007 \\
\hline 5. & 700 & 0,713 & 2,470 & 3,540 \\
\hline 6. & 800 & 0,531 & 2,160 & 2,089 \\
\hline 7. & & & & 1,321
\end{tabular}

Pada variasi kecepatan pengadukan, diperoleh bahwa hasil faktor pisah (FP) $\mathrm{Zr} / \mathrm{Hf}$ yang paling tinggi sebesar 4,007 diperoleh pada kecepatan pengadukan $=500 \mathrm{rpm}$.

Untuk umpan dalam media asam nitrat pada kecepatan pengadukan $500 \mathrm{rpm}$ diperoleh nilai faktor pisah $\mathrm{Zr}$-Hf yang optimum adalah 4,007, efisiensi $\mathrm{Zr}=72,86 \%$, dan efisiensi $\mathrm{Hf}=40,11 \%$. Parameter kecepatan pengaduk perlu dikerjakan karena untuk mengetahui kecepatan yang optimum. Terjadinya perpindahan massa dari fasa air ke fasa organik disebabkan oleh adanya reaksi kimia dan difusi (1).

Dilihat dari sisi reaksi kimia, semakin cepat pengadukan, maka reaksi kimia akan semakin sempurna karena luas tumbukan juga semakin bertambah besar. Apabila ditinjau dari sisi difusi, laju difusi dipengaruhi oleh jarak atau lebar yang ditempuh oleh unsur atau senyawa yang akan mendifusi dari fasa air ke fasa organik. Semakin lebar jarak yang ditempuh maka difusi akan semakin lambat, sehingga untuk memperpendek jarak, maka dilakukan pengadukan yang semakin cepat. Nilai $K_{d}$ akan naik dengan kenaikan kecepatan pengadukan karena intensitas terjadinya tumbukan antara reaktan semakin banyak dan semakin cepat. 


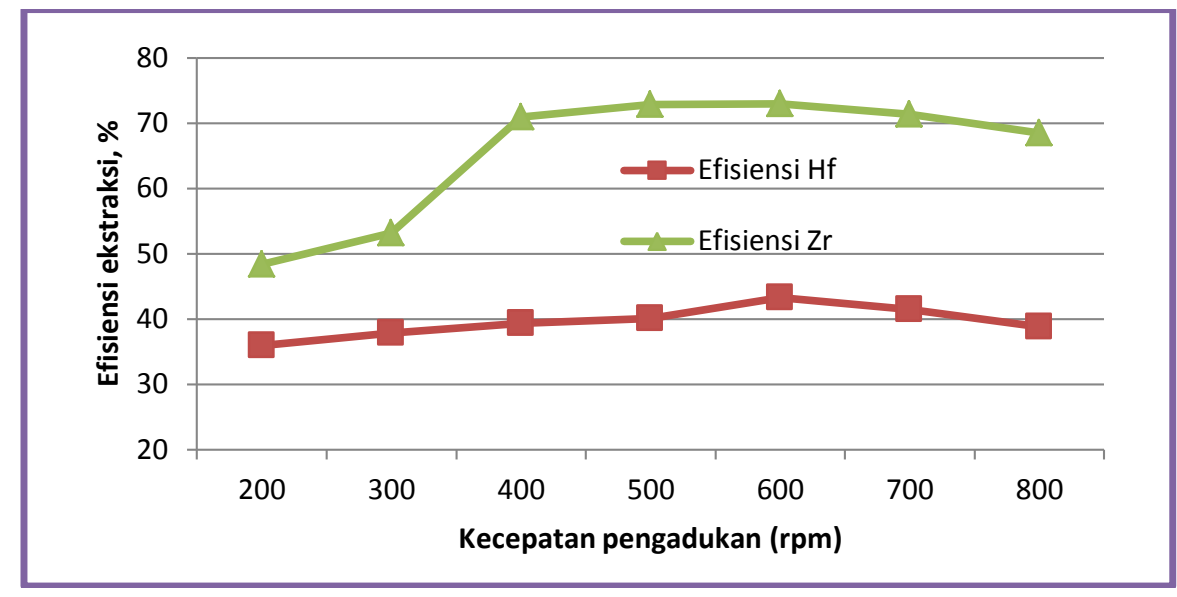

Gambar 2. Pengaruh kecepatan pengadukan (rpm) terhadap efisiensi ekstraksi Zr/Hf.

\section{Variasi Waktu Pengadukan}

Waktu pengadukan atau waktu kontak antara umpan (fasa air) dengan fasa organik (Campuran Cyanex 921 dan TBP dalam kerosen) akan mempengaruhi distribusi $\mathrm{Zr}$ dan $\mathrm{Hf}$ ke dalam fasa organik. Semakin lama waktu kontak antara fasa air dengan fasa organik selama proses ekstraksi maka semakin banyak pula unsur $\mathrm{Zr}$ dan $\mathrm{Hf}$ yang terikat oleh Cyanex 921 dan TBP. Seperti penelitian yang telah dilakukan oleh Purwani dkk.(20) yang menyatakan bahwa waktu pengadukan sangat berpengaruh dalam reaksi kimia pada proses ekstraksi, semakin lama waktu pengadukan akan mengakibatkan semakin banyak solut yang terekstrak ke fasa organik, tetapi setelah mencapai kesetimbangan jumlah solut yang terekstrak akan konstan dan waktu tidak akan berpengaruh lagi. Diperlukan waktu pengadukan yang cukup untuk terjadinya reaksi dan terbentuknya hasil reaksi, sehingga reaksi dan hasil reaksi yang diperoleh maksimal. Hubungan antara koefisien distribusi $\left(K_{d}\right)$, faktor pisah $(F P)$, dan efisiensi ekstraksi (\% E) dengan waktu pengadukan disajikan pada Tabel 3 dan Gambar 3.

Tabel 3. Variasi waktu pengadukan (Perbandingan FA : FO $=1: 1$, kecepatan pengadukan $=500 \mathrm{rpm}$, dan konsentrasi Cyanex $921=12,5 \%$ ).

\begin{tabular}{lcccc}
\hline \multirow{2}{*}{ No. } & $\begin{array}{c}\text { Waktu pengadukan, } \\
\text { menit }\end{array}$ & \multicolumn{2}{c}{ Koefisien distribusi $\left(K_{\mathrm{d}}\right)$} & Faktor pisah $(F P)$ \\
\cline { 3 - 5 } & 5 & $\mathrm{Hf}$ & $\mathrm{Zr}$ & $\mathrm{Zr} / \mathrm{Hf}$ \\
\hline 1. & 10 & 0,670 & 2,685 & 4,007 \\
\hline 2. & 15 & 0,757 & 3,120 & 4,122 \\
\hline 3. & 20 & 0,782 & 3,103 & 4,193 \\
\hline 4. & 25 & 0,786 & 3,174 & 4,115 \\
\hline 5. & 30 & 0,741 & 3,216 & 4,228 \\
\hline 6. & 35 & 0,718 & 2,759 & 3,974 \\
\hline 7. & & & 3,848 \\
\hline
\end{tabular}

Pada variasi waktu ekstraksi, diperoleh bahwa hasil faktor pisah $(F P) \mathrm{Zr} / \mathrm{Hf}$ yang paling tinggi adalah 4,228, yaitu pada waktu ekstraksi $=25$ menit.

Perpindahan massa $\mathrm{Zr}$ dan $\mathrm{Hf}$ dari fasa air ke dalam fasa organik dipengaruhi oleh nilai konstanta difusinya, sehingga perlu dipelajari pengaruh waktu pengadukan (1). Dari Tabel 3. dan Gambar 3. dapat disimpulkan bahwa pada waktu pengadukan setelah 25 menit, $K_{d}$ dan efisiensi ekstraksi ( $\% E$ ) tidak bertambah atau sudah mengalami kesetimbangan. Waktu ini yang dipakai sebagai dasar untuk optimasi parameter yang lain, karena sudah dianggap sebagai waktu kesetimbangan. Setelah tercapai keadaan setimbang, jumlah unsur 
yang terekstrak ke fasa organik sudah tidak lagi dipengaruhi oleh waktu pengadukan. Pada Gambar 3 dapat dilihat bahwa nilai efisiensi ekstraksi $\mathrm{Zr}$ cenderung naik dengan bertambahnya waktu pengadukan. Dengan bertambahnya waktu kontak reaksi akan semakin sempurna sehingga perpindahan massa dari fasa air ke fasa orgnaik semakin banyak. Penetapan kondisi optimum adalah berdasarkan faktor pisah antara $\mathrm{Zr}$ dan $\mathrm{Hf}$. Hasil terbaik diperoleh pada waktu pengadukan selama 25 menit karena dapat memberikan nilai faktor pemisahan $\mathrm{Zr}$ $\mathrm{Hf}$ paling besar yaitu 4,228 dalam suasana asam nitrat.

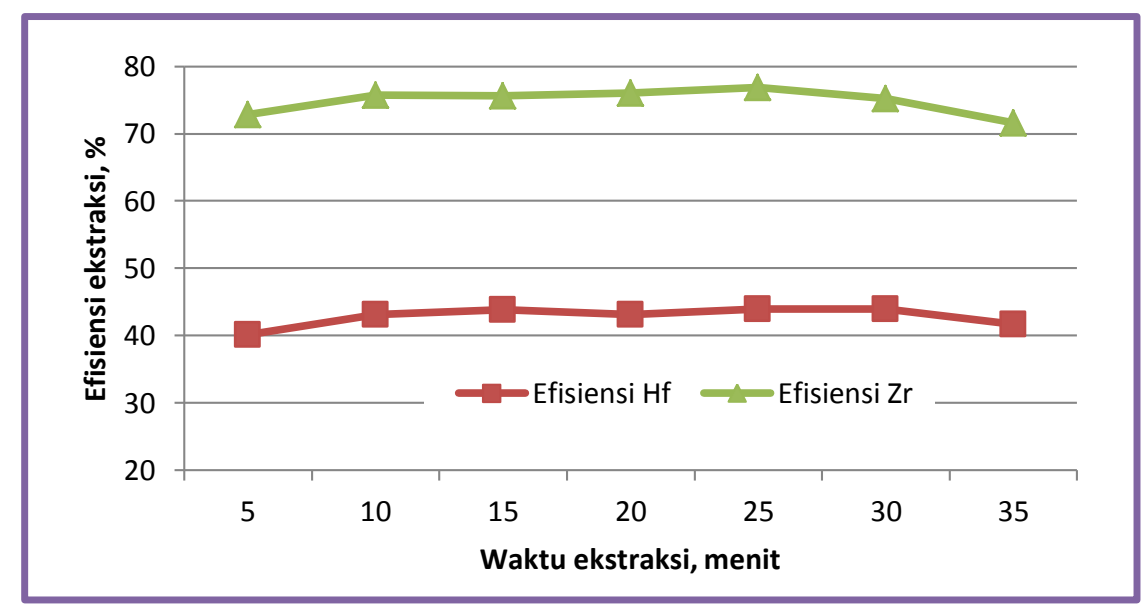

Gambar 3. Pengaruh waktu pengadukan terhadap efisiensi ekstraksi Zr/Hf.

Pengadukan setelah di atas 25 menit terjadi sedikit penurunan faktor pisahnya, hal ini kemungkinan disebabkan karena kemampuan ekstraktan sudah terlewati titik jenuhnya sehingga hasil pemisahannya juga fluktuatif. Selain dipengaruh oleh lamanya waktu pengadukan juga dipengaruhi oleh jari-jari ion logam dan selektivitas ekstraktan Cyanex 921-TBP. Jika ditinjau dari jari-jari atom Zirkonium adalah 0,74 $\AA$ sedangkan Hafnium sebesar $0,75 \AA$, sehingga memungkinkan $Z r$ lebih mudah masuk dan terikat ke dalam ekstraktan dibandingkan dengan $\mathrm{Hf}$.

\section{Variasi Perbandingan Fasa Air Dengan Fasa Organik}

Proses ekstraksi juga dipengaruhi oleh perbandingan volume diluen (fasa air) dengan ekstraktan (fasa organik). Harga koefisien distribusi $\left(K_{\mathrm{d}}\right)$, faktor pisah $(F P)$, dan efisiensi ekstraksi $(\% E)$ dengan perbandingan fasa air dengan fasa organik disajikan pada Tabel 4 dan Gambar 4. Semakin banyak volume fasa organik akan semakin banyak $\mathrm{Zr}$-Hf yang terikat, tetapi pemakaian fasa organik diusahakan sedikit mungkin supaya bisa menghemat pemakaian ektraktan / menghemat biaya.

Pada Tabel 4 dan Gambar 4 ditunjukkan adanya kenaikkan nilai $K_{d}$ dan efisiensi ekstraksi $\mathrm{Zr}$ dan $\mathrm{Hf}$ bersamaan dengan kenaikan perbandingan fasa air dengan fasa organik terhadap efisiensi ekstraksi $\mathrm{Zr} / \mathrm{Hf}$. Selisih kenaikan sebanding dengan perbandingan fasa organik dan fasa air. Hal ini menunjukkan apabila volume fasa organik semakin banyak maka jumlah $\mathrm{Zr} / \mathrm{Hf}$ yang terikat oleh fasa organik semakin banyak pula, dan sebaliknya apabila volume fasa organik semakin sedikit maka jumlah $\mathrm{Zr} / \mathrm{Hf}$ yang terikat oleh fasa organik semakin sedikit pula.

Pada variasi perbandingan fasa air dengan fasa organik (FA : FO), diperoleh bahwa hasil faktor pisah (FP) $\mathrm{Zr} / \mathrm{Hf}$ yang paling tinggi sebesar 5,379 , yaitu pada perbandingan $\mathrm{FA}: \mathrm{FO}=1: 1,5$. Kondisi optimum yang dipilih berdasarkan nilai faktor pisah $(F P)$ antara $\mathrm{Zr}$ dan $\mathrm{Hf}$ yang terbesar. Untuk umpan dalam media asam nitrat pada kecepatan pengadukan $500 \mathrm{rpm}$ diperoleh nilai faktor pisah $\mathrm{Zr}$-Hf yang optimum adalah 5,379, efisiensi $\mathrm{Zr}=$ $81,37 \%$, dan efisiensi $\mathrm{Hf}=44,82 \%$. 
Tabel 4. Variasi perbandingan fasa air dengan fasa organik. (Waktu pengadukan $=25$ menit, konsentrasi Cyanex $921=12,5 \%$, dan kecepatan pengadukan $=500 \mathrm{rpm}$ ).

\begin{tabular}{lcccc}
\hline \multirow{2}{*}{ No. } & $\begin{array}{c}\text { Perbandingan } \\
\text { FA:FO }\end{array}$ & \multicolumn{2}{c}{ Koefisien distribusi $\left(K_{d}\right)$} & Faktor pisah $(F P)$ \\
\cline { 2 - 5 } & & $\mathrm{Hf}$ & $\mathrm{Zr}$ & $\mathrm{Zr} / \mathrm{Hf}$ \\
\hline 1. & $1: 0,5$ & 0,621 & 1,951 & 3,142 \\
\hline 2. & $1: 1$ & 0,786 & 3,323 & 4,228 \\
\hline 3. & $1: 1,5$ & 0,812 & 4,368 & 5,379 \\
\hline 4. & $1: 2$ & 0,890 & 3,085 & 3,466 \\
\hline 5. & $1: 2,5$ & 0,764 & 2,891 & 2,856 \\
\hline
\end{tabular}

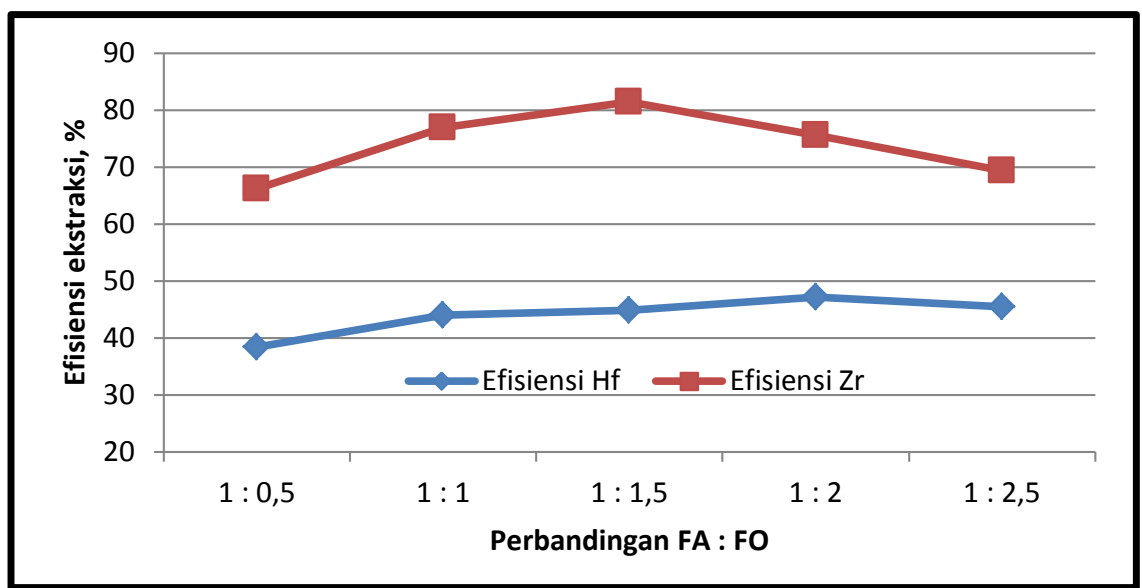

Gambar 4. Pengaruh perbandingan fasa air dengan fasa organik terhadap efisiensi ekstraksi $\mathrm{Zr} / \mathrm{Hf}$.

\section{KESIMPULAN}

Dari hasil penelitian ini dapat disimpulkan bahwa ekstraksi $\mathrm{Zr}$ dan $\mathrm{Hf}$ menggunakan campuran ekstraktan TBP dan Cyanex 921 dipengaruhi oleh konsentrasi Cyanex 921, waktu kontak/pengadukan, kecepatan pengadukan dan perbandingan volume fasa air (larutan umpan) dan fasa organik (ekstraktan). Parameter proses ekstraksi optimum pada penambahan 12,5\% Cyanex 921, waktu pengadukan 25 menit dengan kecepatan pengadukan $500 \mathrm{rpm}$ dan perbandingan fasa organik dengan fasa air 1,5:1. Pada kondisi ini diperoleh faktor pisah $(F P) Z r-H f=6,447$, efisiensi ekstraksi Zr 93,57\% dan Hf 69,31\% serta $K_{d} Z r$ 14,556 dan $K_{d} H f$ 2,258.

\section{UCAPAN TERIMA KASIH}

Pada kesempatan ini penulis ingin mengucapkan banyak terima kasih kepada semua pihak yang telah membantu, terutama Bapak Mulyono, Bapak Iswantoro dan Bapak Sukirno serta rekan-rekan yang lain yang telah banyak memberikan bantuan sehingga selesainya penelitian ini.

\section{DAFTAR PUSTAKA}

1. DWI BIYANTORO, M.V. PURWANI, J.Tek. Bhn. Nukl. Vol. 9 No. 1 (2013), 35-45.

2. XU ZHI-GAO, WANG LI-JUN, WU YAN-KE, CHI RU-AN, ZHANG LI, WU MING, Met. Soc. China 22, (2012), 1760-1765.

3. M. TAGHIZADEH, M. GHANADI, E. ZOLFONOUN, Journal of Nuclear Materials 412, (2011), 334-337.

4. D. J. BRANKEN, G. LACHMAN, H.M. KRIEG, O.S.L. BRUINSMA, Ind. Amp Eng. Chem. Res. 49, (2010), 797-808. 
5. RAJU BANDA, HWA YOUNG LEE AND MAN SEUNG LEE, Ind. Eng. Chem. Res., 51, 28, (2012), $9652-$ 9660.

6. RAJU BANDA, SOO HWAN MIN AND MAN SEUNG LEE, Journal of Chemical Technology and Biotechnology, Volume 89, Issue 11, (2014), 1712-1719.

7. RAJU BANDA AND MAN SEUNG LEE, Solvent Extraction for the Separation of Zr and Hf from Aqueous Solutions, Separation \& Purification Reviews, Volume 44, Issue 3, (2015), 199-215.

8. LING YUN WANG, HWA YOUNG LEE AND MAN SEUNG LEE, Materials Transactions, Vol. 54, No. 8 , (2013), 1460-1466.

9. KRIS TRI BASUKI, DWI BIYANTORO, J. Tek. Bhn. Nukl. Vol. 7 No. 1, (2011), 1-73.

10. UCHIKOSHI, M., MIMURA, K., ISSHIKI, M., Anion-exchange separation of zirconium from hafnium using a multi-column method. TMS Annual Meeting, (2012), 303-314.

11. ENDANG SUSIANTINI, MOCH. SETYADJI, Jurnal IPTEK Nuklir Ganendra, Volume 17, Nomor 1, (2014), 1-8.

12. AGATA JAKÓBIK-KOLON, MAREK SMOLIK, HANNA JAROSZEK, Hydrometallurgy 140, (2013), 77-81.

13. ENDANG SUSIANTINI, MOCH. SETYADJI, Jurnal Teknologi Bahan Nuklir ,Vol 8, No 2, (2012).

14. MOCH. SETYADJI, ENDANG SUSIANTINI, Jurnal Pengembangan Energi Nuklir, Volume 16, Nomor 1 , (2014), 23.

15. L. DELONS, S. LAGARDE, A. FAVRE-REGUILLON, S. PELLET-ROSTAING, M. LEMAIRE, L. PORIEL, Process for the separation and purification of hafnium and zirconium, US Patent number: 770,896 , (2010), 204.

16. O. S. MONNAHELA, W. G. AUGUSTYN, J. T. NEL, C. J. PRETORIUS, J. B. WAGENER, The Vacuum Sublimation Separation of Zirconium and Hafnium Tetrafluoride, PMDN Conference, Cape Town, (2013).

17. J. H. SHIN, M. S. CHOI, D. J. MIN, J. H. PARK, Mater. Chem. Phys. 143, (2014), 1075-1086.

18. C.J. PRETORIUS, A.D. PIENAAR, P.L. CROUSE, AND H.F. NIEMAND, Sublimation Kinetics of Zirconium Tetrafluoride, Advanced Materials Research, Vol. 1019, (2014), 398-405.

19. Anonim, Chemistry Made Simple, Nernst Distribution Law, Metallurgy, (2009).

20. MV PURWANI, PRAYITNO, Jurnal Iptek Nuklir Ganendra Vol. 17 No. 1, (2014), 17-26. 